\title{
DETAILS OF BEING HUMAN
}

\section{ヒトであること}

Nature Vol.454 (21-23) / 3 July 2008

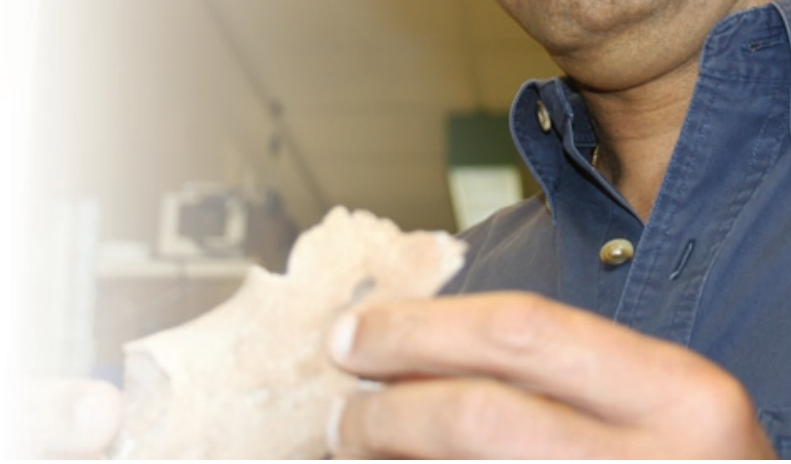

医師の Ajit Varki は、ある 1 つの分子のちょつとした違いを見つけたことから、ヒトと類人猿を隔てるものについて疑 問をもつようになった。微細レベルの現象から人類進化の全体像をとらえようとするこの人物に、Bruce Lieberman が取材した。

ヒトにウマの血清を注射するのは好まし くない。Ajit Varkiがこれに気づいた のは、まだ若い医師だった 1984 年、 サンディエゴで、骨髄機能不全の女性 患者に血清を投与したときのことだっ た。女性の丁細胞が骨䯣を破壊するの を止めるには、当時、ウマ血清の投与 が標準的な治療法の 1 つだった。しか し、こうした血清療法は「血清病」と よばれる反応を引き起こすことも知られ ており、案の定、治療の 1 週間後、女 性にじんましんが出た。そこでVarkiは、 これは女性の免疫系が異種動物に由来 するタンパク質に攻撃を仕掛けた結果 ではないかと考えた。

女性患者の反応の観察後間もなく、 この反応がタンパク質だけではなく、シ アル酸、つまり哺乳類の細胞表面を覆 う糖も原因であることがわかった。当時 既に、いくつかの研究によって、ウマ血 清に含まれるN-グリコリルノイラミン酸 (Neu5Gc) というシアル酸の一種に 対して、ヒト免疫系が応答することが示 唆されていたのである。「どうしてそう なるのだろうか」Varkは、そのとき思っ
たことを覚えている。「シアル酸に対す る応答はどうして起こるのか。シアル酸 はどこにでもある。すべての哺乳類はシ アル酸をもっているのだ」。Varki は、 ヒトが実はNeu5Gc をもたない唯一の 哺乳類なのではないかと考えた。

Varki は医師でありながら生化学も おさめており、既に当時、糖鎖生物 学 (glycobiology) という比較的新 しい分野の研究に従事していた。糖鎖 生物学とは、細胞の内外にあるさまざ まなタンパク質や脂質を修飾する糖鎖 を対象とした研究分野である。しかし、 当初抱いた疑問に対する答えを得る チャンスが巡ってくるまでには、この後 14 年を要した。1998 年にVarki は 同僚たちと、高性能の液体クロマトグラ フィーを使って、チンパンジーやボノボ、 ゴリラ、オランウータン、そしてヒトの 血液検体を分析した。すると、ヒトが Neu5Gc をもたない唯一の霊長類であ ること 、その代わりにヒト細胞にはNアセチルノイラミン酸（Neu5Ac）とい う別のシアル酸であるが豊富にあるこ とがわかった。

\section{進化の研究に乗り出す}

これらの成果をきっかけに、Varki は糖 鎖生物学の第一人者としてだけでなく、 尊敬を集める「名誉」古人類学者とし ての道も歩み始めた。彼は、学際的な 研究機関、人類発生学研究·教育センター (CARTA) の共同設立者の 1 人であり、 現理事の 1 人でもある。CARTA は、カ リフォルニア大学サンディエゴ校と、近 くのラホヤにあるソーク研究所との共同 研究組織で、ニューヨーク州に本部のあ る G. Harold \& Leila Y. Mathers 財 団から 300 万ドル(約 3 億 3000 万円) の資金援助を受けて、今年 (2008 年) 3 月に創設された。

CARTAの名称にある「人類発生学 (Anthropogeny)」は、人類の進化 と個体発生の両方を対象とする研究を 意味し、古い世代の人類学者にとっては なじみ深い言葉である。Varkiによれば、 この言葉の中には、ヒトの脳が現在の機 能を、いつ、なぜ、どのように進化させ たのかといった、人類の起源研究におけ る最大の疑問のいくつかが含まれている という。彼の最新の研究プロジェクトの 
1 つに、マドリード・コンプルテンセ大 学のスペイン人古生物学者Juan Luis Arsuaga との共同研究がある。その目 的は、スペイン北部のアタプルカで出土 した 90 万年前のホモ・アンテセソール (Homo antecessor) の化石を生化学的 に解析することである。この化石はヨー ロッパでこれまでに見つかった最古級の 人類の骨として知られている。Varki が 探し求めているのは、Neu5Gc が人類 進化のごく初期に失われたことを示す証 拠である。ヒトが、ヒトだけがNeu5Gc を失ったことが人類の出現に関係してい るのではないか、と彼は考えているのだ。

Varkiの「知りたい」というどん欲さ は、彼が糖鎖生物学者から人類起源に 関する学際的研究センター理事という道 を歩む推進力となった。「彼はまさに百 科事典のような人物です」。こう評する のは、テキサス大学サウスウェスタン医 療センター（ダラス）の糖鎖生物学者、 Mark Lehrman である。「Varki は 人類学の正規の教育を受けていないに もかかわらず、独学でこの分野を究め、 権威になったのです。まさにそうなるよ うに、天から与えられた驚くべき才能の 持ち主なのです」。

Varki は最初、インドのベロールに あるキリスト教医科大学で総合内科医 の研修医としてキャリアをスタートし た。その後、医師と研究者の両面を兼 ね備えた専門家をめざして米国に渡り、 1970 年代にはついに、ワシントン大学 (ミズーリ州セントルイス) の Stuart Kornfeld の下で特別研究員となった。

そのころKornfeld は、シアル酸な どの糖鎖に関する研究を始めたばかり だった。当時、糖鎖生物学は、ほとん ど手つかずの分野であり、このような 未知の生物学にかかわる機会を得た Varkiは、大いに興味をそそられた。 その後 1982 年に、Varki はカリフォ ルニア大学サンディエゴ校に自身の糖 鎖生物学研究室をもち、現在もそこで 研究を行っている。

Neu5Gc と Neu5Acの違いは分子 レベルでは非常に小さく、Neu5Gcの
腕部分に 1 個の酸素原子が付加されて いるかどうかで区別される (下図を参照 のこと)。しかし、生物学レベルでは、こ の違いは途方もなく大きい可能性がある。 「もしサルやヒトに近縁な類人猿がすべ てNeu5Gcをもっており、ヒトだけがもっ ていないとすれば、そこには分子レベル の要因があるはずだと考えられました」 とVarki はいう。彼はその後、Neu5Ac をNeu5Gc へ変換する酵素にその要因 を見つけた。ヒトではこの酵素が変異に よって機能不全になっているのである ${ }^{2}$ 。

\section{進化の選択圧}

Varki の発見によって、チンパンジーと ヒトを生化学的に隔てる決定的な違い が 1 つ明らかになった、とウェイン州立 大学 (ミシガン州デトロイト) の進化生 物学者、Morris Goodmanは語る。 シアル酸の例は、そうした違いで最初 に見つかったものの1つだった。しか もシアル酸は、主に細胞認識分子や細 胞接着因子として、さまざまな生物学的 役割を果たしているので、この違いに よってヒトに固有の生物学的特性の一部 を説明できるかもしれない。「我々が今 取り組んでいる対象は、全身に影響を 及ぼす遺伝子久損の 1 つなのです」と Goodman は話す。

Varki はその当時、自分が学部生の 時代に学んだことや『ナショナルジオグ ラフィック』誌で読んだこと以外に、人
類の進化についてほとんど知識がない ことを痛感していた。そこで彼は、自分 の知識を高めようとした。彼は休暇を取 り、短期間ではあるが、ジョージア州ア トランタにある米国立ヤーキス霊長類 研究センターで生活したのである。彼 は 1 人の獣医とともに動物たちの医療 記録を再検討し、ヒトに広くみられる関 節リウマチや気管支ぜんそくが、同セン ターの霊長類ではそれまで一例もない ことを知った。また、チンパンジーはヒ トの熱帯熱マラリア原虫 (Plasmodium falciparum) でマラリアにかかることは なく、反対に、ヒトはチンパンジーに病 原性のあるマラリア原虫 P. reichenowi には感染しない。

その後の研究で、Varki と彼の研究 チームは、ヒトとチンパンジーのマラリ ア感染性の違いはシアル酸の違いによ ることを明らかにした。チンパンジー に感染するP. reichenowi は、チンパン ジーの赤血球表面にあるNeu5Gcに 結合する傾向が強いが、ヒ卜感染性の 熱帯熱マラリア原虫はNeu5Acのほう に選択的に結合する ${ }^{3}$ 。そこでVarki たちは、ヒトではP. reichenowi の感 染を回避する方向に選択圧が働き、 Neu5Gc 欠失とこの原虫に対する耐性 の獲得につながったのではないか、そ して今度はこの欠失が結果的に後押し する形となって、Neu5Acに結合して ヒト体内に侵入できるような熱帯熱マラ

小さい変化、大きな違い

人類進化の最中に生じた変異だとすれば、ヒトではシアル酸Neu5Acまでしか 作られず、ヒト以外の霊長類ではNeu5AからNeu5Gcも作られることになる。

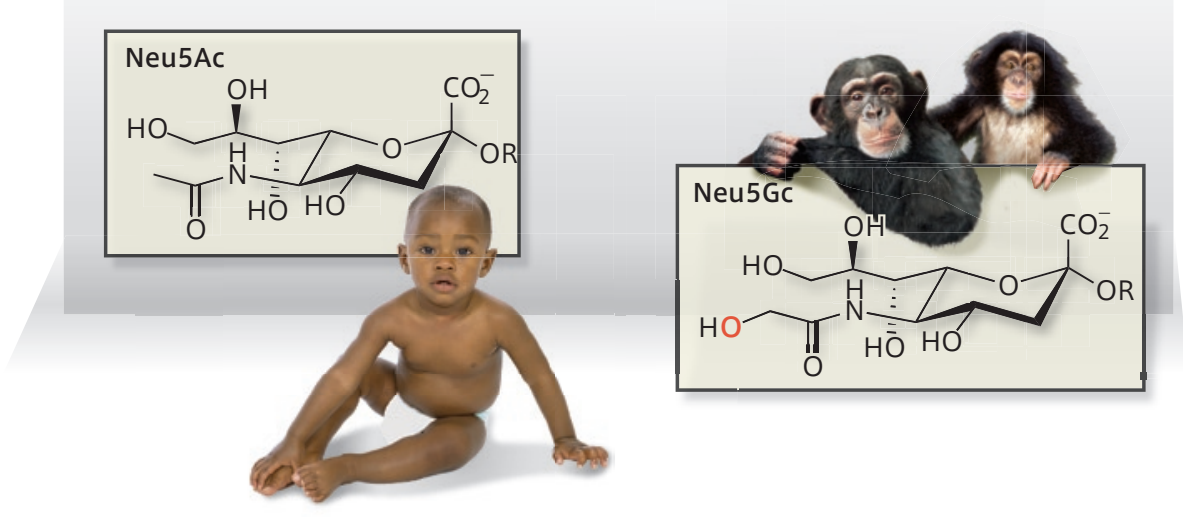


リア原虫が出現したのではないかとす る仮説を立てた。Varkiの研究室では そのほかにも、シアル酸の機能に影響 を及ぼす、ヒト特異的な別の 10 種類 の遺伝的変異などを発見している。こ れらの知見は、ヒトがアルツハイマー 病や多発性硬化症などにかかりやすい 理由を、これまでにない視点から説明 するのに役立つかもしれない。

ほどなくして、Varki の人類進化への 関心は、チンパンジーとその糖鎖をはる かに超える域にまで広がった。Varkiの 長年の共同研究者で友人でもある、ソー ク研究所の Fred Gage は、「Varki が キャンパスで数人と話しているのを知 り、『そんな風に 1 対 1 で会話をして、 話したことを共有しようとしないなんて フェアじゃないね』といったことがあり ますよ」と冗談っぽく語った。

\section{人類発生学の再考}

Gage はVarki に、人類の起源につい て大学で非公式の連続セミナーを開催す るよう勧めた。その「人類の起源を説明 するためのプロジェクト」には、1998 年から 2007 年までの間に、古人類学 者、霊長類生物学者、遺伝学者、免疫 学者、神経科学者、言語学者その他さ まざまな分野の研究者が集まった。そし て、言語の進化から、人類とネアンデル タール人とホモ・エレクトゥス（アフリ カを出た最初の人類）の間の差異まで、

著作権等の理由により画像を掲載することができません。

ホモ・アンテセソールの化石の検証により、人類進 化の早期にNeu5Gc が失われたことが実証されるか もしれない。
幅広い話題について議論を交わした。 Goodman によれば、このセミナーシ リーズは、さまざまな学問分野にまたが る学際的な性格をもっており、人類起源 の研究にとって極めて重要な存在になっ たという。「我々は、人類の進化上の起 源に関係する問題を探求するすばらしい 機会を手に入れたのです」と彼は語った。

Varkiの動機には、自分のため、とい う部分もあった。「心中で密かに決め ていた目標の 1 つは、自分自身の理解 を深めるということでした」と彼は認め ており、「最後の会合のときに、自分が 人類学の学士号をとれるかどうか、参加 者に尋ねてみました」といった。Varki 自身が数えたところでは、この研究分野 のさまざまな面について、研究者の話を 300 件以上聞いたという。「これらの問 題に関して、言語学者は分子生物学者 、、分子生物学者は神経科学者へ、神 経科学者は心理学者や哲学者へ向かっ て話す必要があると考えたからです」と 彼はいう。「人間の知識の大部分は、ど こかで関連し合っているものなのです」。

CARTA は、人類起源に関するセミ ナーシリーズの後継プロジェクトである。 CARTA の理事として、VarkiやGage のほか、カリフォルニア大学サンディ エゴ校の人類学教授である Margaret Schoeninger、Varkiと親しい共同 研究者で霊長類生物学者のPascal Gagneuxらが名を連ねている。さらに
同センターには、サンディエゴに活動拠 点を置くメンバーがおよそ 40 人、それ 以外に米国各地や米国外のメンバーが 100 人以上もいる。

CARTA の目標は、こうした世界中の 研究者どうしの連携を促し、大型霊長 類の研究リソースへ容易にアクセスでき るようにし、論文審査のある学術専門 誌を育て、人類の起源に関する研修講 座をお膳立てすることである。このプロ ジェクトは、ある意味では、ドイツで設 立されたライプチヒ人類起源研究スクー ルに匹敵する。同スクールは、ライプチ ヒにあるマックス・プランク進化人類学 研究所とライプチヒ大学が 2005 年か ら共同で進めている学際的な PhD 取得 プログラムである。Varki は、「CARTA はそれよりもっと本格的な組織となるだ ろうし、この努力によって研究分野の壁 が取り払われるはずです」と語り、その 一例として自身のシアル酸に関する研 究を引き合いに出した。この研究では、 生化学者、古生物学者、医師の間の共 同研究が必要だったのである。

\section{シアル酸の検査}

VarkiとGagneuxは研究室に戻って 数か月以内に、アタプルカで出土した 動物の化石の予備解析に取りかかる 予定である。高性能液体クロマトグラ フィーと質量分析を使って、保存されて いるシアル酸を検出できるかどうか調べ

\section{MDMMMNMMMMMMMM}

シアル酸

シアル酸とは、 9 個の炭素をもつアミノ九炭糖酸、ノイラミン酸の誘導体の総称。 生体物質として 30 種類以上が知られており、自然界では $N$-アセチルノイラミ ン酸（Neu5Ac）が最も多く、次いでN-グリコリルノイラミン酸（Neu5GC） が多くみられる。おもに、動物細胞膜や分泌液の糖タンパク質や糖脂質の糖鎖 末端に結合し、細胞の増殖・分化、神経繊維の発達などに関係すると考えられ ている。Neu5Gc はNeu5Ac の水酸化によって生成されるが、ヒトはこの水 酸化酵素に欠損があり、Neu5GCをもたない。このため、異種間臟器移植や 異種血清の投与により、免疫系がこの糖鎖を認識し、抗体が産生される。 
ようというのだ。もしその動物の化石か らシアル酸が検出されれば、同じ地層 から出土した人類の化石にもシアル酸 が保存されている可能性が高いとみら れ、Varkiたちは続いてそれを調べる ことになるだろう。

「古生物学者は、既に終わって過ぎ 去った物ごとに関心がある人たちだと思 われることが多いです。しかし、我々が 追い求めているのは、現生人類の出現 の説明であり、そのことが忘れられてい るのです」とArsuagaはいう。彼によ れば、現在の技術で骨に孔を開けて内 部から少量の骨粉を採取すれば「損傷 はさほど大きくない」から、と説得され て、貴重なホモ・アンテセソールの化 石に種々の検査を行うことに同意した のだという。

Varki と Gagneux は、Neu5Gc と人類進化におけるその役割に関す るいくつかの壮大な仮説に解答を出 すのに、アンテセソールの化石が役 立ってほしいと考えている。2人は、 Neu5Gc を欠失させる变異が初めて 出現したのは、 200 万〜 300 万年前 の人類の祖先においてであると概算し ている。これはホモ・エレクトゥスの 出現年代と一致している。また、彼ら は、マラリアなどの病原体がこの变化 のきっかけとなった可能性があると考え ている。2人は、この遍在する糖に起 こった変化が、別の広範な生物学的作 用を及ぼし、それがNeu5Gcをもつ 動物ともたない動物との間に生殖的隔 離が生ずる一因となったのではないか、 そして、これらの作用がホモ・エレク トゥスとその後のホモ・アンテセソー ルの出現に寄与したのではないかと考 えている。「Neu5Gcの欠失は生存に 必要なものだったかもしれませんが、 Neu5Gc を保持している「旧型」の仲 間全体との生殖を抑制するように働い た可能性もあります」とGagneuxは 語る。もし、Arsuaga のホモ・アンテ セソール化石も Neu5Gc を欠いている ことを明らかにできれば、彼らの仮説 を裏づける新たな証拠となるだろう。
この種分化仮説への答えが古代の人 類から得られなかった場合には、きっ とマゥスが役に立ってくれるだろう。 Varki とGagneuxは、ヒトにはない Neu5Gc シアル酸を遺伝子操作で欠損 させたマウスを作り出した。Varkiによ ると、これらの変異マウスにはヒトに少 し似た特徴がみられるという４。野生型 マウスと比べると、変異マウスは聴覚が 劣っており、ヒトの加齢に伴う聴覚の衰 えをどこか連想させる。また、外傷の治 り方も遅く、これはほかの霊長類に比 ベてヒトの外傷の治り方が遅いのと似て いる。さらなる研究によって、これらの 変異マウスが、Neu5Gcを保持してい る野生型のマウスと交配して繁殖できる かどうかを明らかにすべきだろう。

Varki の最近の研究は、彼自身が 25 年前に観察した免疫応答へと回帰して いる。ヒトはNeu5Gc を作り出すこと はできないが、それを含む肉や乳など の動物性食品で摂取することができる。 Varki とGagneuxは、少なくとも肉 食の場合にはNeu5Gc が免疫応答を 引き起こし、それが、ヒトに固有の心疾 患やがんといった慢性的炎症を伴うさま ざまな疾患全体に関与しているのでは ないかと考えている。こうした疾患は、 ヒトの寿命が今より短かったころには、 さほど問題ではなかったのだろう。

\section{思考の糧}

この説を検証するため、Gagneuxは 地元のホールフーズマーケット（自然 食品や有機栽培食品を扱うチェーン店） に出かけて、食肉や乳製品を買い込み、 解析用に研究室に持ち帰った。解析の 結果、ラム肉书豚肉、牛肉でNeu5GC の值が最高であることがわかった。 「我々は大きなボール何杯分も食べ、 自分たちの糖タンパク質に結果が現れ ているかどうかを調べるために、その後 数週間にわたって、自分たちから可能な かぎりすべての解析用検体を採集しまし た」とGagneuxはいう。「そして、そ の答えはイエスでした」。また、研究チー ムは、多くの人がこの糖に対する抗体を

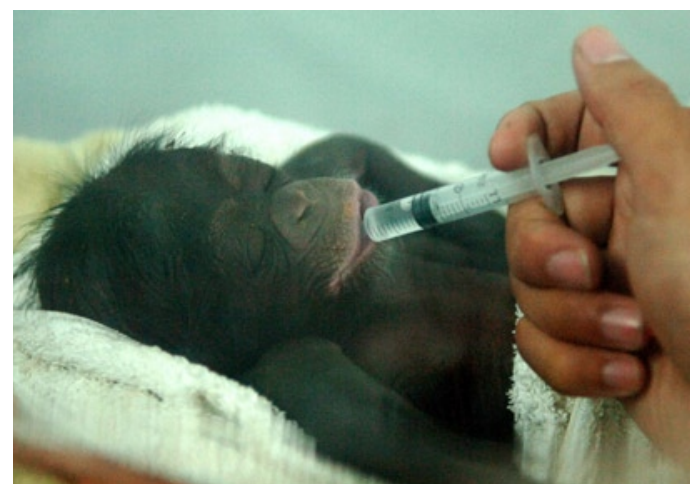

チンパンジーとヒトのシアル酸の違いによって、一部 の疾患に対する感受性（かかりやすさ）が変わる。

もっていることも見つけ出した 5 。

彼らの仮説が裏づけられた場合には、 選択圧がどのように変化するのかが明 らかになるだろう。つまり、かつては 人類を病原体から守るためにNeu5Gc 欠失が進化上選択されたのに、現在は その欠失のせいで、人類がほかの疾患 にかかりやすくなっていると考えられる。 「いったんそれを失ってしまえば、現在 もっているもので間に合わせるほかあり ません」とVarki は話す。

患者を診療することからキャリアを始 めたVarki にとって、シアル酸と人類 の起源の研究は原点に立ち返らせるも のである。ヒトをヒトたらしめた分子 は、脅威となる疾患に対するヒ卜固有の 脆弱さをもたらす分子と同じなのかも しれない。「場合によっては、それらの 分子は人類進化の傷跡といえるのでは ないかと思います」とVarki はいう。「私 自身、経験を積んだおかげで、我々が 何者で今どこに向かっているのかを理解 するには、我々自身の起源となる人類 進化の解明がとても重要だという事実 を受け入れられるようになりました」。

Bruce Lieberman は、サンディエゴ在住のフ リーランスのサイエンスライター。

1 Muchmore, E. A. et al. Am. J. Phys. Anthropol. 107, 187-198 (1998)

2. Chou, H.-H. et al. Proc. Natl Acad. Sci. USA 95, 1175111756 (1998).

3. Martin, M. J.etal. Proc. NatlAcad. Sci. USA 102, 1281912824 (2005).

4. Hedlund, M. et al. Mol. Cell. Biol. 27, 4340-4346 (2007).

5. Tangvoranuntakul, P. et al. Proc. Natl Acad. Sci. USA 100, 12045-12050 (2003). 